\title{
A Semi-official Defence of Islam
}

BY A. MINGANA

IN cataloguing the Oriental MSS. of the John Rylands Library, I came across an unknown and semi-official defence of Islam. The MS, containing it is in some places in a bad state of preservation, but apart from about ten words which have completely faded away, the text has been read ${ }^{1}$ and translated, and it is hoped that the book, accompanied by a critical apparatus, will shortly be published by the Governors of the Library at the Manchester University Press.

In perusing the work, I was struck by the insignificance of the changes that the twentieth century theology has brought into the domain of religious controversies. The work is probably an answer to the apologies of Christianity by the Nestorian Patriarch Timothy (about A.D. 783) and al-Kindi (about 830), but I doubt whether it might not have been also an answer to $M \bar{z} z \vec{a} n u$ ul- $H a l k l$ of Pfander, if the learned Doctor of Divinity had written his book at the time of the caliphs Mahdi and Ma'mūn or Mutawakkil.

It is natural in a discussion between a Christian and a Muhammadan, that the latter should dilate on the claims of his "master" to be the prophet of God, in proving that his Kur'ann is the word of God. The first point comprises many minor subdivisions, in which we should expect to find prophecies from the Old and New Testaments referring to Muhammad, miracles wrought by him in imitation of Christ and Moses, and various other considerations likely to base his historicity on unassailable foundations. When all these points have been established, the debater had to indicate the timeliness of the religious innovations, if any, in which his

1 I shall gratefully acknowledge my indebtedness to Professor D. S. Margoliouth, of Oxford, for help in the decipherment of some half obliterated words. The MS. is written in Baghdad in 616/1219 
Prophet might have indulged in the proclamation of his message.

Our Defence harps on the above theme, and according to the caliph who caused it to be written, in a happy and scientific manner. After giving some good suggestions to be followed in discussions, the author proceeds: "I have found that people who have contradicted Islam have done so for four reasons: (1) because of doubts about the history of the Prophet-may God bless and save him ; (2) because of their pride and insolence; (3) because of their traditions and customs ; (4) because of their folly and stupidity."

After telling us that in the second part of his book he will establish the historicity of the Prophet beyond a shadow of doubt, he ends his first chapter as follows: "We shall next compare our stories with theirs, the men who transmitted them to us with those who handed them down to them; if the proofs that we have for believing in our Prophet are the same as those they possess for believing in theirs, they will have no excuse before God and before their own conscience for disbelieving in our Prophet though believing in theirs, because if two opponents bring forth the same evidence to establish certain claim they have both the same right to it, and what is due to one must necessarily be due to the other."

The frame of the controversy has been contrived so as to comprehend the following ten points set forth in the third chapter: "( $(a)$ The call of the Prophet was to One, Eternal, Omniscient, and Just God, whom no one can overcome and hurt; (b) he was pious, upright, sincere, and his laws and prescriptions are praiseworthy ; $(c)$ he wrought clear miracles which only the prophets and the chosen ones of God can work; $(d)$ he prophesied about events hidden from him, which took place during his lifetime; $(e)$ he prophesied about many events concerning this world and its kingdoms, which were realized after his death; $(f)$ he brought forth a book which by necessity and by undeniable arguments is a sign of prophetic office; $(g)$ his victory over the nations 
is also by necessity and by undeniable arguments a manifest sign of prophetic office; $(h)$ his disciples who transmitted his history are most honest and righteous men, to whose like nobody can attribute lie and falsehood; $(i)$ he is the last of the prophets, and if he had not been sent the prophecies of the prophets about him and about Ishmael would have been vain; $(j)$ the prophets prophesied about him long before his appearance, and described his mission, his country, his time, and the submission of nations to him and of kings to his nation." Each one of these points forms the subject of a special and long chapter.

The final chapters treat of the status of the Arabs before the appearance of Muhammad and contain an "answer to those who have pretended that no one but the Christ has mentioned the Resurrection, and to those who have reprobated the fact that the Prophet should have contradicted Moses and Christ in changing the ways of acting of the Torah and the Gospel, and to those who have said that the Refugees and the Helpers embraced the Muslim faith without having seen any miracle, and finally to those have blamed Islam in one of its ways of acting or in one of its prescriptions".

The author of the Defence is the famous physician 'Ali, son of Rabban at-Tabari, who died about A.D. $865,{ }^{1}$ but he frequently acknowledges his indebtedness to the caliph Mutawakkil (842-62), who, to quote his own words, "guided me and made me profit by words heard from him."

At the end of the introduction the notorious caliph is spoken of in the following terms : " $\mathrm{He}$ is in earnest and eager that such books should be spread and perpetuated in order to strengthen the motives of credibility of the faith and to convince of his merits therein those who ignore it and do not recognize how God has singled out Islam and its followers in his time, renewed for them His benefits, and made himself

1 In the Introduction I have collected all the available data concerning his life and his works. 
known to them in multiplying, increasing, and honouring them by the gentleness of his administration."

The conclusion of the work is as follows: "I first thank God for His guidance to me, then His Servant and Caliph Ja'far al-Mutawakkil 'ala-Allah, Commander of the Faithfulmay God prolong his life--who invited and attracted me to him along with other people of the tolerated cults, by persuasion and dissuasion, and by the respect and consideration that he has for all. It is for this reason that I devoted the first chapter of this book to describe what my nation has felt from his munificence, the tokens of his mercy, the gentleness of his administration, the prosperity of his reign, and the great number of his conquests."

In the third chapter we are told that the Defence was written at the urgent request of the Caliph and his advisers: "It is he-may God prolong his life-who called me to this work, guided me in it and laid before me on account of it a great reward and a good memory." The work was therefore written within the limits of 842-62. From numerous other data, which it would be too long to analyse here, we may safely infer that the probable date of the composition of the Defence is 850-5.

Dualists, Magians, Buddhists, Jews, are here and there mentioned and sharply attacked, but as in the golden age of the 'Abbasid Caliphate the Christian community was more numerous and powerful than all the other bodies of the "tolerated sects", the nasāra are the principal adversaries.

In the chapter which deals with the prophecies relating to Ishmael, the "wild-ass of men", the author applies to his opponent the uncivil epithets of " rude Garmecite, stupid, ignorant, dolt, blockhead", but from a man in the court of Mutawakkil we should have expected even harsher expressions; indeed, it is only fair to say that the author, apart from this chapter, has scrupulously followed the counsels which he gives in his introduction: "He who writes a book on this high, illuminating, and enlightening subject, which involves a 
general utility to adherents to all religions, has to make it understandable and easy ; has to discuss with his adversary, convince him, compete with him, and not to behave proudly against him; he is to be fair and not to abuse ... if he does that, he will ride on him, hit him with his arrow and lead him with his bridle."

The Defence is important, throwing as it does great rays of light upon the early development of Muhammadanism as contrasted with the more liberal Muhammadans of our days. We will only draw attention to two items taken at random.

The doctrine of the holy war is set forth in a most uncompromising manner, and is even considered essential to the existence and the welfare of the world. With a view to its vindication, quotations are adduced from the old and New Testaments, and the example of Abraham, Joshua, and other warlike Patriarchs is thrown into relief. Here is how the writer concludes one of his paragraphs: "As to the Prophet -may God bless and save him-he ordered with persuasion and dissuasion to worship One, Eternal, and Omnipotent God in order that religion might be one and the Supreme Being One; he who responds to that has the prerogatives and the obligations of the Muslims, and he who does not respond but gives tribute on his hand in a humble condition (Kor. ix, 29), he spares his blood with this tribute and is tolerated upon his submission; but he who refuses that, war shall be behind him. This constitutes a fine subject of meditation for the unbelievers; indeed, it lowers down their amour propre and their pride, and calls the people of honour and self-esteem from amongst them to change their state of lowliness and toleration by means of tribute, for the glory of dignity and freedom."

The existence of sensual pleasures in heaven is maintained with all its crudity. In the thirtieth chapter we read the following words: "If somebody reprobates the saying of the Prophet that in the world to come there is food and drink, the answer would be that the Christ told also such a thing 
to his disciples when he drank with them and said to them ' I will not drink of this fruit of the vine, until I drink it another time with you in the kingdom of heaven' (Matt. xxvi, 29). In this he declared that in heaven there is wine and drink, and where drink is found, food and pleasures are not blamed."

Further, the Old Testament is constantly quoted with regard to kiblah, divorce, circumcision, fight against unbelievers, and retaliation.

The author has displayed much ingenuity in finding the name Muhammad in the Bible. Being a Christian by birth, ${ }^{1}$ he read Syriac perfectly, and there is also reason to believe that he knew some Greek and Hebrew, because he resorts sometimes to textual criticism in Scripture. For all practical purposes, however, the Peshițta Version, the Vulgate of the Eastern Churches, is the text used by Tabari. He frequently appeals to an Arabic translation of the Bible by a certain Marcus, whom he calls " the Interpreter", but whom I am still unable to identify with any other writer known to me either in Syriac or in Arabic literature.

The pith of his Biblical argumentation lies in the fact that he has gathered all the texts which deal with warlike expeditions, conquests, slaughter, wilderness, desert, and referred them to the Prophet.

What is more curious and ingenious in his method is the translation of the Aramaic adjective Meshabbha by Muhammad. Linguistically speaking this translation is often correct, but sometimes ludicrous; so Ps. xlviii, 1-2, is rendered thus : "Great is our Lord, and he is greatly Mahmüd; and in the city of our God and in his monntain there is a Holy One and a Muhammad." In Is. xli, 16, we have also "And thou shalt rejoice and become Muhammad in the Holy One of Israel ", and in Is. lv, 7, "Because of the Lord, thy God, the Holy One of Israel, who hath made thee Ahmad."

1 Incidentally we may remark that the prevalent opinion (Brock.i, 231) that he was of Jewish origin is erroneous 
More important to scholars are the chapters which deal with the historicity of the Prophet. The writer has registered on this subject many oral traditions in circulation at the court of the 'Abbasids. He was evidently satisfied with the outcome of his researches, for he says in the third chapter : "I wish the reader of this book to realize its merits and the excellency of its value, and to know that those born in the religion of Islam and firmly attached to it who have profusely dealt with this subject did not reach what I have attained. He who has a doubt in his breast let him compare my book, the prophecies, the convincing and peremptory proofs which it contains, with all that other writers have written since the appearance of Islam down to our own time. This is due to the help and the assistance of God, and to the blessings of the Commander of the Faithful-may God strengthen him."

So far as the Prophet's personality is concerned, I think that the author is right in his judgment, because his work constitutes a precious repertory of traditional sayings, some of which are unregistered by Ahmad b. Hanbal, Bukhāri, Muslim, and Tirmidhi, and missing in the histories of Ibn Islı̣āk, Wāḳidi, Ibn Sa'd, and Tabari.

According to the author, the Christians do not believe in the mission of Muhammad for three main reasons: First, because they do not see that a prophet has prophesied about him prior to his coming; second, because they do not find in the Kur'ān the mention of a miracle or a prophecy ascribed to the man who brought it forth ; third, because the Christ has told them that no prophet will rise after Him. These, the writer adds, "are their strongest objections, and I will refute them by the help of God."

The system followed in the vindication of the history of the Prophet is according to the author very felicitous; from the last chapter we extract some typical passages in which he is interpellating the Christians as follows : "Moreover, among those who handed down to you those stories of yours there was none who claimed that he had taken them from 
an eye-witness among his fathers or grandfathers who had seen the Christ or Moses-peace be with them-as the Arabs claim on the authority of their fathers and their grandfathers who have seen the Prophet-peace be with him. . . . Your stories have been handed down to you by a man of 'Irāk, who took them from a man of Jazīrah, who in his turn took them from a man of Syria; or by a Syrian, who took them from a Hebrew ; or by a Persian, who took them from a Greek, through obscure and irregular channels."

These are some aspects of this ancient and unique Defence which from a Muslim standpoint has doubtless an unparalleled value, its very title being Religion and Empire. 